\title{
Effect of Combination of Some Natural Products and Chloroquine on HCV Infection in Egyptian Patients: Pilot Study
}

Zaki Sheir ${ }^{1}$, Gamal Badra ${ }^{2 *}$, Ossama Salama ${ }^{1}$, Asmaa I Gomaa ${ }^{2}$ and Wesam Saber ${ }^{2}$

${ }^{1}$ Mansoura University, Egypt

${ }^{2}$ National Liver Institute, Menoufiya University, Egypt

\begin{abstract}
Background: Studies using safe natural products $\left\{\right.$ Blue green ${ }^{\circledR}$ tablet (Rhodiola rosea L. root dry extract; Eleutherococcus senticosus Maxim. root dry extract; Ginkgo biloba L. leaf dry extract; Klamath microalgae Aphanizomenon flos aquae (AFA) $50 \mathrm{mg}$ )\} showed its antiviral effect. As well as vitamin D3, linolenic acid, black seeds and honey. The aim of the study was to determine the efficacy of combination of these natural products and chloroquine in treatment of HCV patients refusing or unfit for combined Interferon and Ribavirin (INF/RBV) therapy or HCV patients who failed to achieve sustained virological response to INF/RBV.
\end{abstract}

Methods: Patients with detectable HCV RNA with different stages of fibrosis and cirrhosis refusing or unfit for combined Interferon Ribavirin (INF/RBV) therapy or patients who failed to achieve sustained virological response to INF/RBV from April 2009 to March 2012 were included in this study. All the patients were treated first from coinfection as schistosomiasis and helicobacter pylori if present then received combination Blue green ${ }^{\circledast}$ tablet-original natural company, Italy; 2 tablet/30 kg once daily; Vitamin D: 1000 IU/day; tablespoon filled with paste made of linolenic acid, black seeds powder and honey; and $250 \mathrm{mg}$ chloroquine once daily for 10 days and then every 3 days through the duration of therapy.

Results: 195 patients with chronic HCV were included; mean age $47.8 \pm 9.03$ years, $67.7 \%$ males. All patients have chronic hepatitis. 24 patients had cirrhosis. 82 (42.1\%) achieved negative HCV RNA after 6 months of treatment. After 12 months of treatment, 107 (54.9\%) patients had negative HCV RNA. 125 (64.3\%) patients achieved ETR after 18 months of treatment. Moreover, 4/6 (66.6\%) patients with combined HCV and HBV showed undetectable HBV after 3 months. Two out of 8 (25\%) patients who failed to achieve SVR with previous (INF/RBV) have ETR.

Conclusion: Combination of safe natural products (Blue green ${ }^{\circledast}$ tablet, vitamin D3, linolenic acid, black seeds and honey) and chloroquine may have a role to achieve SVR in combination with recent direct acting antiviral drugs for HCV infection.

Keywords: Hepatitis C virus (HCV); Natural products; Chloroquine; Rhodiola rosea L; Ginkgo biloba L leaf dry extract; Klamath microalgae Aphanizomenon flos aquae (AFA)

\section{Introduction}

Hepatitis C virus is a global infection with an estimated 170 million people affected [1]. It appears that there are endemic strains which have persisted in specific locations for many centuries. These can be readily identified by viral genotype. There have been iatrogenic outbreaks leading to massive spread of specific subtypes in countries such as Egypt (genotype 4A) [2,3]. HCV heterogeneity is huge based on its capacity to develop mutations through its error-prone polymerase and its very long co-evolutionary history with man. Clinically genotype information on the virus is of major importance in defining response to conventional as well as newer therapies [4].

HCV infection is a major health problem in Egypt $[5,6]$. The current standard of care for hepatitis C infection is peginterferon/ribavirin, it gives higher sustained response rates in genotype $2 / 3$ infected individuals [7]. But in Egypt the infection is due to genotype 4A for which is less affected by this type of therapy, beside its high cost and numerous serious side effects [8]. This obliged us to search for a safe effective therapy which is less costly as $\mathrm{HCV}$ infection is more common in patients with low socioeconomic status. In addition, they are immunocompromised by parasitical infections such as Schistosomiasis and pollution of food by aflatoxins and toxic carcinogenic insecticides.

Since 1983, the blue green algae Aphanizomenon flos-aquae (AFA) has been harvested from Upper Klamath Lake (UKL) in Southern
Oregan and marketed as a dietary supplement. It is consumed for its putative beneficial effects including detoxification, increasing energy, elevating mood and loss of weight [9]. Several compounds were extracted from blue green algae including a protein called Cyanovirin- $\mathrm{N}$ (CV-N) which appears to irreversibly inactivate diverse strains of HIV virus [10]. CV-N has antiviral activity against $\mathrm{HCV}$ as it inhibits HCV entry into host cells at low nanomolar concentrations [11]. Also, blue green algae compounds selectively inhibit the penetrations of enveloped viruses (Herpes simplex, human cytomegalovirus, measles virus, mumps virus, influenza virus and HIV virus) into host cells thereby preventing replications [12-14]. Also, consumption of AFA has rapid effect on the circulation of immune cells in humans [15]. The WHO approved that the daily intake of AFA algae is $2 \mathrm{~g} /$ day (WHO).

Chloroquine, the known antimalarial drug exerts direct antiviral effect inhibiting $\mathrm{pH}$ dependent steps of the replication of several viruses including members of the flavin viruses, retro viruses and corona

*Corresponding author: Gamal Badra, National Liver Institute, Menoufiya University, Egypt, E-mail: gamalbadra@yahoo.co.uk

Received January 09, 2013; Accepted January 28, 2013; Published January 30, 2013

Citation: Sheir Z, Badra G, Salama O, Gomaa Al, Saber W (2013) Effect of Combination of Some Natural Products and Chloroquine on HCV Infection in Egyptian Patients: Pilot Study. J Liver 2: 116. doi:10.4172/2167-0889.1000116

Copyright: (C) 2013 Sheir Z, et al. This is an open-access article distributed unde the terms of the Creative Commons Attribution License, which permits unrestricted use, distribution, and reproduction in any medium, provided the original author and source are credited. 
viruses. Moreover, it has immunomodulatory effects suppressing the production/release of tumor necrosis factor $\alpha$ and interleukin 6 which mediate the inflammatory complications of several viral diseases [16].

Recent research showed that vitamin $\mathrm{D}$ has an important role in innate immune response against HCV [17]. In addition some studies have shown that vitamin $\mathrm{D}$ improves insulin sensitivity (a prediction of liver treatment response) and inhibit HCV replication [18]. Earlier findings [19] specifically in Middle East [20] showed beneficial effect of adding supplement of vitamin D to current standard treatment of HCV as evidenced by improving both early and sustained virological responses. Rhodiola rosea used in the treatment of depression [21,22] has also antiviral effect against Coxsackieviruses [23]. It has also hepatoprotective effect.

Milk thistle is a known herbal medicine for treatment of HCV used in conjunction to conventional therapies [24]. Ginkgo biloba has hepatoprotective effects against $\mathrm{CCl}_{4}$-induced oxidative damage may be due to its antioxidant and free radical-scavenging activity [25]. It represses hepatitis $C$ viral replication in $\mathrm{HCV}$ viral replication in HCV genotype $1 \mathrm{~B}$ replicon cell [26]. As all the preceding agents are safe and there is no known non beneficial interaction between them, combination of these agents may be synergetic. This encouraged us two use this combination to treat cases of HCV infection in Egyptian patient. Besides we urged our patients to consume honey, black seeds paste and olive oil in their diet as honey is mentioned in Quran to have beneficial effects to cure patients. Black seeds paste has more beneficial effect than black seed oil as during preparation of oil, there is loss of some beneficial volatile acid. Black seed has immunomodulatory effect [27]. Olive oil contains fat soluble vitamins specially vitamin D and also rich in linoleic acids that has decreasing effect on HCV replication [28]. This work was conducted to determine the efficacy of combination of safe natural product; blue green ${ }^{\circledR}$ tablet, vitamin D3, black seeds, olive oil and honey; and chloroquine in treating naive patients with chronic hepatitis $\mathrm{C}$ and non-responders to combined IFN/RBV treatment.

\section{Patients and Methods}

This study enrolled $195 \mathrm{HCV}$ naive patients refusing INF/RBV therapy. Also, patients who failed to achieve sustained virological response to combined Interferon Ribavirin therapy (INF/RBV) whether PEGylated or conventional interferon were included if they stopped the antiviral treatment at least 3 months before recruitment. This study included patients with different stages of fibrosis and patients with compensated cirrhosis. All the patients were treated first from co-infections as schistosomiasis, helicobacter pylori and bacterial infections. Also, nutritional deficiencies were treated before starting treatment of $\mathrm{HCV}$ viral infection with a combination of natural products of (Blue green ${ }^{\circledR}$ tablet one tablet $/ 30 \mathrm{~kg}$, vitamin, tablespoon full of paste of black seeds, olive oil, and honey) and chloroquine.

Blue green ${ }^{\circledR}$ original natural company, Italy; each tablet contains (Rodiola rosea L.) root dry extract (entitled to $1 \%$ in salidroside); eleuterococco (Eleutherococcus senticosus Maxim.) root dry extract (entitled to 5\% in saponin); Ginkgo (Ginkgo biloba L.) leaf dry extract (entitled to $24 \%$ in ginkgoflavonglycosides and $6 \%$ in lactones terpenic); Klamath microalgae (Aphanizomenon flos aquae $50 \mathrm{mg}$ ); equiseto (Equisetum arvense L.) cauli sterili). The WHO approved that the daily intake of Aphanizomenon flos aquae (AFA) as food supplement is 2 $\mathrm{gm} /$ day (WHO). It is recommended from the pharmaceutical company to start with 2 Blue green ${ }^{\circledR}$ tablets/day in empty stomach to prevent gastric upset and can be increases to 4 tablets daily, that was notified to ministry of health in Italy in accordance with art 7 NO 111/1992. In early phase of the study the effect of two tablets daily was not satisfactory so we increased the dose on weight base to 4 tablets daily (equivalent to $100 \mathrm{mg} \mathrm{AFA} / 30 \mathrm{~kg} \mathrm{BW}$ ) This dosing was more convenient to the patients with less cost.

Chloroquine was used at dose of $200 \mathrm{mg} \mathrm{mg} /$ day for one year for the treatment of HIV (Paton et al. [29]). To reduce the side effect, in this study chloroquine was used in the regimen of treatment and prophylaxis's of malaria $(250 \mathrm{mg} /$ day for 10 days and then every 3 days along the duration of therapy). Vitamin D (1000 IU/day) was used in the recommended daily doses and recommendation reported by Abu Mouch et al. [20], which used Vitamin D supplement to improve SVR in chronic hepatitis $C$ (genotype 1) naive patients treated with peg interferon and ribavirin.

\section{Subject selection}

Patients included in the study fulfilled the following inclusion criteria: their age 18 years or older, positive Anti-HCV antibody, detectable serum HCV-RNA by quantitative PCR. While patients were excluded if there is evidence of HCC, severe concurrent medical disease such as severe hypertension, heart failure, significant coronary heart disease, poorly controlled diabetes, chronic obstructive pulmonary disease and pregnant women were excluded. All subjects gave written, informed consent before participating in the study.

All patients were subjected to full history taking and thorough clinical examination and the following tests before treatment: abdominal ultrasonography, AST, ALT, serum bilirubin, serum albumin, prothrombin concentration, complete blood count, serum creatinine, viral markers ( $\mathrm{HCV} \mathrm{Ab}, \mathrm{HBs} \mathrm{Ag}$ ). IHA for schistosomiasis and helicobacter antigen in stool were tested for before treatment. Detection of HCV RNA level by PCR quantitative measurements by COBAS Amplicor 2.0, Roche Molecular Diagnostics, Pleasanton, CA, USA (lower limit of detection of $50 \mathrm{IU} / \mathrm{mL}$ ) was done before treatment. All patients had been followed up every three months with physical examination, hematological studies, liver and kidney function tests and abdominal ultra-sonograms. Quantitative HCV-RNA by PCR test was done for each patient after 3, 6, and 12 and 18 months of treatment.

\section{Statistical analysis}

For the descriptive statistics after having checked the normality of the variables using the Kolmogorov-Smirnov test, the usual central and dispersion methods were used: average, SD, and 95\% CI. The statistical significance of differences between the means were evaluated using the paired Student $s t$ test in the case of normal distribution of data sets, and using the Kolmogorov-Smirnov test when at least in one of the data sets the normal distribution was excluded. The independent Student $t$ test was used to compare the means of continuous variables and the normal distribution data. Otherwise, the Mann-Whitney U test was used. All statistical analyses were performed using SPSS (statistical package for social science) program version 17 for windows and differences were considered significant at 0.05 . Results were given as mean and standard deviation.

\section{Results}

The Demographic data and present history are shown in table 1 . 195 patients were included in this study whose age ranged from 20 years to 76 years. The mean age was $47.8 \pm 9.03$ years. 132 patients $(67.7 \%)$ were males while 63 patients were females (32.3\%). 57 patients (10.8\%) were diabetics, 4 (2.3\%) of patients suffered from bilharziasis. 6 patients $(3.4 \%)$ had minimal ascites. 8 patients had history of previous 


\begin{tabular}{|l|c|}
\hline Variables & Value \\
\hline Age at presentation (years): Range & $20-76$ \\
Mean \pm SD & $47.8 \pm 9.03$ \\
\hline Gender (M/F) & $132 / 63$ \\
\hline Bilharziasis $\mathrm{( \% )}$ & $57(10.8)$ \\
\hline Ascites n (\%) & $6(3.4)$ \\
\hline DM n (\%) & $17(9.8)$ \\
\hline Liver $\mathrm{n}(\%)$ (Abdominal ultrasound) & $80(40.8)$ \\
Normal & $91(46.9)$ \\
\hline Fatty & $24(12.2)$ \\
\hline Cirrhotic & $125(64.2)$ \\
\hline Spleen $\mathrm{n}(\%)($ Abdominal ultrasound) & $62(31.9)$ \\
Normal & $5(2.4)$ \\
Mild enlarged & $3(1.5)$ \\
\hline Huge & $8(4.1)$ \\
\hline Splenectomy & \\
\hline Previous IFN therapy $\mathrm{n}(\%)$ & \\
\hline
\end{tabular}

Table 1: Demographic data of the included patients.

INF therapy with no response. 6 patients had combined HCV with HBV infection.

The Mean ALT, AST, Total bilirubin and prothrombin concentration were $54.31 \pm 40.26,56.66 \pm 39.97,1.01 \pm 0.73,77.11 \pm$ 19.09 respectively. The mean creatinine, hemoglobin, total leukocyte count and platelets were $0.93 \pm 0.14,12.52 \pm 2.06,4879.41 \pm 1983.08$ and $143416.69 \pm 72938.82$ respectively. The mean HCV RNA was $505538.30 \pm 1208201.18$ as shown in table 2 . Table 3 showed that mean ALT level before treatment was $52.87 \pm 36.97$ compared to mean ALT level after treatment $38.12 \pm 16.47$ with highly statistical significant difference $(\mathrm{p}<0.01)$. While mean AST level before treatment was 53.46 \pm 36.11 compared to mean AST level after treatment $41.61 \pm 17.27$ with highly statistical significant difference $(\mathrm{p}<0.01)$. Mean bilirubin level before treatment was $0.96 \pm 0.29$ compared to mean bilirubin level after treatment $0.98 \pm 0.34$ with no statistical significant difference $(\mathrm{p}>0.05)$.

In this study, 67/195 patients (34.1\%) showed rapid virological response to treatment after 3 months. 82/195 patients (42.1\%) showed early virological response to treatment after 6 months (Table 4 and figure 1). After 12 months of treatment, 107 patients (54.8\%) showed negative HCV RNA by PCR (Figure 2). 125 patients (64.1\%) showed end treatment response to treatment after 18 months of treatment (Figure 3 ). Moreover, the $4 / 6$ patients with combined HCV and HBV showed complete response for HBV after 3 months. Two out of 8 (25\%) patients who failed to achieve SVR with previous (INF/RBV) have ETR. There was highly statistical significant association ( $\mathrm{p}$ value $<0.01$ ) between initial HCV RNA level and end of treatment response (347851.32 \pm 109928.55). Also, there was statistical significant association ( $p$ value $<0.05$ ) between initial AST level and end of treatment response $(51.49 \pm 32.93)$ as shown in table 5. There is no statistical association ( $\mathrm{p}$ value $>0.05$ ) between end of treatment response and all other studied variables as ALT, bilirubin, albumin levels, INR CBC or age. Other 22 patients showed 2 log decrease of initial HCV RNA after 12 months of treatment but they could not reach negative HCV RNA by PCR at 18 months. There was highly statistical association ( $\mathrm{p}$ value $<0.01$ ) between initial HCV RNA level and 2 log decrease of HCV RNA (1462923.71 $\pm 205800.24)$ as shown in table 6 . There was no statistical association between all other studied variables and 2 log decrease of initial HCV RNA (Figure 4).

\section{Discussion}

The current standard treatment is expensive and also has numerous serious side effects and is only effective in approximately $50 \%$ of patients. In addition, relapse after SVR may occur [30]. Combination therapy of IFN- $\alpha$ and ribavirin against HCV does not target the virus directly. IFN- $\alpha$ is believed to strengthen the host's innate antiviral immune response through activation of Janus-activated and tyrosine kinases and through a signal cascade it causes transcription of various genes encoding for proteins that interfere with the virus replicative complex [31]. Regarding ribavirin, the mechanism of action is not well understood; probably it exerts its action through immunemodulatory effects [32]. Drugs target specific viral proteins; especially NS3-4A serine protease and NS5B polymerase are promising. Different peptidomimetic inhibitors, nucleoside analogs, and non-nucleoside analogs are at various stages of development and show high potency against $\mathrm{HCV}$. However, these drugs show a high susceptibility for resistance emergence as detected by in vitro studies. In most cases, one single point mutation is sufficient to achieve tolerance against the drug or worsen cross mutations against another one [33]. These observations indicate that drug resistance is likely to remain a problem, and new drugs targeting viral proteins will not be enough to prevent resistance emergence.

\begin{tabular}{|l|l|}
\hline Variables & Mean \pm SD \\
\hline ALT range & $7-275$ \\
& $54.31 \pm 40.26$ \\
\hline AST range & $4-261$ \\
& $56.66 \pm 39.97$ \\
\hline Total bilirubin range & $0.1-7.0$ \\
\hline PC range & $1.01 \pm 0.73$ \\
\hline Creatinine Range & $31-100$ \\
\hline HB Range & $77.11 \pm 19.09$ \\
\hline WBCs Range & $0.7-1.2$ \\
\hline Platelets Range & $0.93 \pm 0.14$ \\
\hline Initial HCV RNA Range & $7.8-16.8$ \\
\hline
\end{tabular}

Table 2: Initial liver functions, serum creatinine and complete blood picture of the studied cases.

\begin{tabular}{|c|c|c|c|}
\hline Variables & Mean \pm SD & Paired $t$ test & $p$-value \\
\hline ALT before treatment & $52.87 \pm 36.97$ & \multirow{2}{*}{3.28} & \multirow{2}{*}{$<0.01^{*}$} \\
\hline ALT after treatment & $38.12 \pm 16.47$ & & \\
\hline AST before treatment & $53.46 \pm 36.11$ & \multirow{2}{*}{2.69} & \multirow{2}{*}{$<0.01^{*}$} \\
\hline AST after treatment & $41.61 \pm 17.27$ & & \\
\hline Bilirubin before treatment & $0.96 \pm 0.29$ & \multirow{2}{*}{0.63} & \multirow{2}{*}{$>0.05^{\star}$} \\
\hline Bilirubin after treatment & $0.98 \pm 0.34$ & & \\
\hline
\end{tabular}

*Wilcoxon test

Table 3: Differences between liver functions before and after treatment.

\begin{tabular}{|l|c|}
\hline Variables & No (\%) \\
\hline $\begin{array}{l}\text { Rapid virological response (3 months) } \\
\text { Responder }\end{array}$ & $67(34.4)$ \\
\hline $\begin{array}{l}\text { Early virological response (6 months) } \\
\text { Responder }\end{array}$ & $82(42.1)$ \\
\hline $\begin{array}{l}\text { virological response at 12 months of treatment } \\
\text { Responder }\end{array}$ & $107(54.9)$ \\
\hline $\begin{array}{l}\text { End treatment response (18 months) } \\
\text { Responder }\end{array}$ & $125(64.3)$ \\
\hline $\begin{array}{l}\text { Two log decrease of initial HCV RNA } \\
\text { Positive }\end{array}$ & $129(66.1)$ \\
Negative & $66(33.9)$ \\
\hline
\end{tabular}

Table 4: Virological response of the studied cases. 


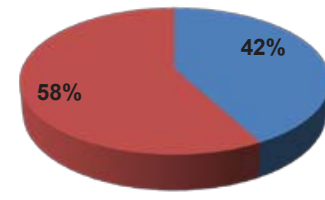

- Responder

Non responder

Figure 1: Virological response after 6 months of treatment.

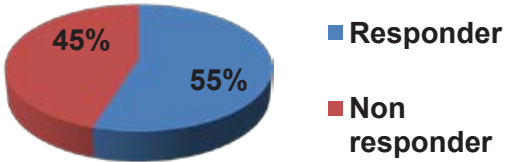

Figure 2: Virological response after 12 months of treatment.

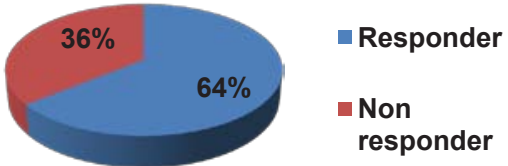

Figure 3: Virological response after 18 months of treatment.

\begin{tabular}{|c|c|c|}
\hline Variables & Mean \pm SD & p-value \\
\hline Age & $47.81 \pm 8.53$ & $>0.05$ \\
\hline ALT & $52.51 \pm 39.96$ & ${ }^{*}>0.05$ \\
\hline AST & $51.49 \pm 32.93$ & ${ }^{*}<0.05$ \\
\hline Bilirubin & $0.93 \pm 0.32$ & ${ }^{*}>0.05$ \\
\hline Serum Albumin & $3.99 \pm 0.34$ & $>0.05$ \\
\hline INR & $81.25 \pm 25.94$ & $>0.05$ \\
\hline HB & $12.43 \pm 1.55$ & $>0.05$ \\
\hline WBCs & $4600.00 \pm 2103.97$ & $*>0.05$ \\
\hline Platelets & $121000.05 \pm 74365.56$ & $*>0.05$ \\
\hline Initial HCV RNA & $347851.32 \pm 109928.55$ & $*<0.01$ \\
\hline
\end{tabular}

*Mann Whitney test

Table 5: Univariate analysis of age, liver functions, $C B C$ and initial HCV RNA in relation to end treatment response.

\begin{tabular}{|c|c|c|}
\hline Variables & Mean \pm SD & p-value \\
\hline Age & $46.32 \pm 7.64$ & $>0.05$ \\
\hline ALT & $50.45 \pm 24.04$ & ${ }^{*}>0.05$ \\
\hline AST & $58.80 \pm 30.82$ & ${ }^{*}>0.05$ \\
\hline Bilirubin & $1.15 \pm 0.49$ & ${ }^{*}>0.05$ \\
\hline Serum Albumin & $3.94 \pm 0.34$ & $>0.05$ \\
\hline INR & $59.57 \pm 4.67$ & $>0.05$ \\
\hline HB & $12.33 \pm 3.37$ & $>0.05$ \\
\hline WBCs & $4825.00 \pm 1558.58$ & ${ }^{*}>0.05$ \\
\hline Platelets & $172750.00 \pm 97448.70$ & ${ }^{*}>0.05$ \\
\hline Initial HCV RNA & $1462923.71 \pm 205800.24$ & ${ }^{*}<0.01$ \\
\hline
\end{tabular}

*Mann Whitney test

Table 6: Univariate analysis of age, liver functions, CBC and initial HCV RNA in relation to 2 log decrease of initial HCV RNA.

The lack of vaccine for HCV infections, the high cost of the drugs specially in low-income countries with a high prevalence of $\mathrm{HCV}$, ineffective therapy and the rapid emergence of new drug-resistant viruses have urged a growing need for developing new, more effective chemotherapeutic agents with less side effects for successful HCV treatment. Takeshita et al. at the university of Miyazaki in Japan believed that since HCV is localized in the liver and can take 20 years or more to develop into disease, dietary supplement might help slow or stop disease progression [34]. Consumption of AFA has rapid effects on the circulation and function of immune cells in humans. Jensen et al. [35] conducted a randomized, placebo-controlled study to examine the short-term effects of consumption of 1.5 grams of the blue green algae Aphanizomenon flos-aquae (AFA), on the immune system. They found that consumption of an AFA results in rapid changes in immune cell trafficking i.e. generalized mobilization of lymphocytes and monocytes, but not polymorph nucleated cells. This included increases in $\mathrm{CD}^{+}, \mathrm{CD}^{+}$, and $\mathrm{CD}^{+} \mathrm{T}$ cell subsets and $\mathrm{CD} 19^{+}$ $\mathrm{B}$ cells with reduction in relative proportions and absolute numbers of Natural Killer (NK) cells. The polymorph nucleated cells showed a mild but significant reduction in phagocytic activity. In vitro, AFA did not induce a direct activation of lymphocytes, as evaluated by tyrosine phosphorylation and proliferative activity. They concluded that AFA increases the immune surveillance without directly stimulating the immune system [15].

Recently there have been many scientifically-controlled studies analyzing the immune enhancing properties of Aphanizomenon flos-aquae (AFA) from Klamath Lake, Oregon. On the basis of the Provisionally Tolerable Daily Intake (PTDI) I value established by the $\mathrm{WHO}$, a guidance value of $1 \mu \mathrm{g}$ microcystin-LR/g AFA algae was issued for AFA algae in the USA and the daily intake of AFA algae is $2 \mathrm{~g}$ per person weighted $60 \mathrm{~kg}$ [36].

Many patients in Egypt including those who are not eligible for IFN/ribavirin, cannot afford treatment, or fail to respond to IFN, use natural products as alternative treatment for HCV infection.

To our knowledge, this is the first study designed to evaluate the effect of combination of natural products in Egyptian patients with chronic HCV. Our results showed that combination of BGA, Vitamin D, black seeds, olive oil and honey and chloroquine affect significantly serum ALT and AST levels. The viral load decreased significantly with treatment. Furthermore, the decrease in viral load was related to the duration of treatment. The virological response was $64.3 \%$ after 18 months of treatment.

Baicus and Tanasescu [37] studied the effect of one month treatment of Spirulina (extract of blue green algae) on serum aminotransferases and general state, compared to placebo, in 24 patients with chronic HCV. They found no effect on the level of aminotransferases with improvement in the general status. However, these results may be due to the very short duration of treatment. Yano et al. [38] found that three nutrients $\beta$-carotene, vitamin D2, and linoleic acid inhibited HCV RNA replication in a cell culture system and that their combination caused additive and/or synergistic effects on HCV RNA replication.

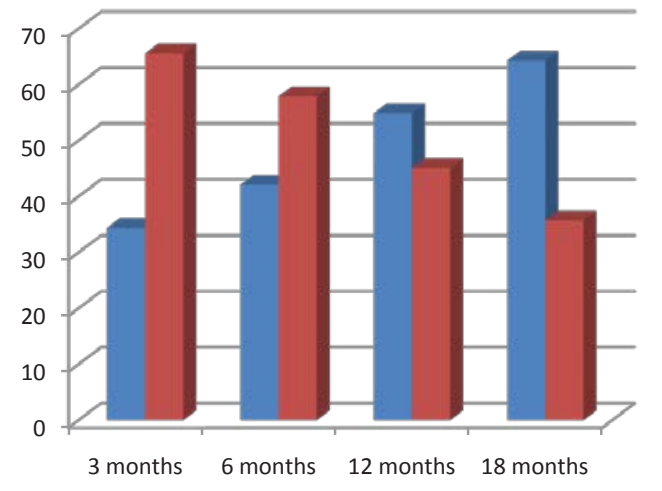

- Responder

Non responde

Figure 4: Virological response after treatment. 
Citation: Sheir Z, Badra G, Salama O, Gomaa Al, Saber W (2013) Effect of Combination of Some Natural Products and Chloroquine on HCV Infection in Egyptian Patients: Pilot Study. J Liver 2: 116. doi:10.4172/2167-0889.1000116

\section{Conclusion}

Combination of safe natural products (Blue green ${ }^{\circledR}$ tablet, vitamin D3, linolenic acid, black seeds and honey) and chloroquine may have a role in treating patients with chronic $\mathrm{HCV}$ in combination with recent direct acting antiviral drugs.

\section{References}

1. Lauer GM, Walker BD (2001) Hepatitis C virus infection. N Engl J Med 345 41-52.

2. Pybus OG, Barnes E, Taggart R, Lemey P, Markov PV, et al. (2009) Genetic history of hepatitis C virus in East Asia. J virol 83: 1071-1082.

3. Pybus OG, Charleston MA, Gupta S, Rambaut A, Holmes EC, et al. (2001) The epidemic behavior of the hepatitis C virus. Science 292: 2323-2325.

4. Simmonds $P$ (2004) Genetic diversity of the hepatitis $C$ virus- 15 years on. J Gen Virol 85: 3173-3188.

5. WHO (2002) WHO Traditional Medicine Strategy 2002-2005.

6. Sievert W, Altraif I, Razavi HA, Abdo A, Ahmed EA, et al. (2011) A systematic review of hepatitis $C$ virus epidemiology in Asia, Australia and Egypt. Liver Int 31: $61-80$.

7. Camma C, Di Bona D, Schepis F, Heathcote EJ, Zeuzem S, et al. (2004) Effect of peginterferon alfa-2a on liver histology in chronic hepatitis $\mathrm{C}$ : a meta-analysis of individual patient data. Hepatology 39: 333-342.

8. Kamal SM, Nasser IA (2008) Hepatitis C genotype 4: what we know and what we don't yet know. Hepatology 47: 1371-1383.

9. Gilroy DJ, Kauffman KW, Hall RA, Huang X, Chu FS (2000) Assessing Potential Health Risks from Microcystin Toxins in Blue-Green Algae Dietary Supplements. Environ Health Perspect 108: 435-439.

10. Boyd MR, Gustafson KR, McMahon JB, Shoemaker RH, O'Keefe BR, et al (1997) Discovery of cyanovirin-N, a novel human immunodeficiency virusinactivating protein that binds viral surface envelope glycoprotein gp120: potential applications to microbicide development. Antimicrob Agents Chemother 41: 1521-1530.

11. Helle F, Wychowski C, Vu-Dac N, Gustafson K, Voisset C, et al. (2006) Cyanovirin-N Inhibits Hepatitis C Virus Entry by Binding to Envelope Protein Glycans. J Biol Chem 281: 25177-25183.

12. Hayashi K, Hayashi T, Kojima I (1996) A natural sulfated polysaccharide calcium spirulan, isolated from Spirulina platensis: in vitro and ex vivo evaluation of anti-herpes simplex virus and anti-human immunodeficiency virus activities. AIDS Res Hum Retroviruses 12: 1463-1471.

13. Ayehunie S, Belay A, Baba TW, Ruprecht RM (1998) Inhibition of HIV-1 replication by an aqueous extract of Spirulina platensis (Arthrospira platensis). J Acquir Immune Defic Syndr Hum Retrovirol 18: 7-12.

14. Schaeffer DJ, Krylov VS (2000) Anti-HIV activity of extracts and compounds from algae and cyanobacteria. Ecotoxicol Environ Saf 45: 208-227.

15. Jensen GS, Hart AN, Zaske LA, Drapeau C, Gupta N, et al. (2007) Mobilization of human CD34+ CD133+ and CD34+ CD133(-) stem cells in vivo by consumption of an extract from Aphanizomenon flos-aquae--related to modulation of CXCR4 expression by an L-selectin ligand? Cardiovasc Revasc Med 8: 189-202

16. Savarino A, Boelaert JR, Cassone A, Majori G, Cauda R (2003) Effects of chloroquine on viral infections: an old drug against today's diseases. Lancet Infect Dis 3: 722-727.

17. Adams JS, Hewison M (2010) Update in vitamin D. J Clin Endocrinol Metab 95: $471-478$

18. Bouillon R, Carmeliet G, Verlinden L, van Etten E, Verstuyf A, et al. (2008) Vitamin $D$ and human health: lessons from vitamin $D$ receptors null mice. Endocr Rev 29: 726-776.

19. Petta S, Camma C, Scazzone C, Tripodo C, Di Marco V, et al. (2010) Low vitamin $D$ serum level is related to severe fibrosis and low responsiveness to interferon-based therapy in genotype 1 chronic hepatitis C. Hepatology 51 1158-1167.

20. Abu Mouch S, Fireman Z, Jarchovsky J, Assy N (2010) Vitamin D supplement improve SVR in chronic hepatitis $C$ (genotype 1) naive patients treated with peg interferon and ribavirin. 45th Annual Meeting of the European Association for the Study of the Liver (EASL 2010). Vienna, Austria.

21. Darbinyan V, Aslanyan G, Amroyan E, Gabrielyan E, Malmstrom C, et al. (2007) Clinical trial of Rhodiola rosea L. extract SHR-5 in the treatment of mild to moderate depression. Nord J Psychiatry 61: 343-348.

22. Jeong HJ, Ryu YB, Park SJ, Kim JH, Kwon HJ, et al. (2009) Neuraminidase inhibitory activities of flavonols isolated from Rhodiola rosea roots and their in vitro anti-influenza viral activities. Bioorg Med Chem 17: 6816-6823.

23. Wang H, Ding Y, Zhou J, Sun X, Wang S (2009) The in vitro and in vivo antiviral effects of salidroside from Rhodiola rosea L. against coxsackievirus B3. Phytomedicine 16: 146-155.

24. Azzam HS, Goertz C, Fritts M, Jonas WB (2007) Natural products and chronic hepatitis $C$ virus. Liver Int 27: 17-25.

25. Naik SR, Panda VS (2007) Antioxidant and hepatoprotective effects of Ginkgo biloba phytosomes in carbon tetrachloride-induced liver injury in rodents. Liver Int 27: 393-399.

26. Weihang H (2011) Bilobalide, a major ingredient of Gingko Bilioba leaves, represses hepatitis C viral replication in HCV genotype 1b Replicon cells AASLD.

27. Tariq M (2008) Nigella sativa seeds: folklore treatment in modern day medicine Saudi J Gastroenterol 105-106.

28. Irmisch G, Hoeppner J, Thome J, Richter J, Fernow A, et al. (2011) Serum fatty acids, antioxidants, and treatment response in hepatitis $C$ infection: greater polyunsaturated fatty acid and antioxidant levels in hepatitis $C$ responders. $J$ Clin Lipidol 5: 288-293.

29. Paton NI, Aboulhab J, Karim F (2002) Hydroxychloroquine, hydroxycarbamide, and didanosine as economic treatment for HIV-1. Lancet 359: 1667-1668.

30. Feuerstadt P, Bunim AL, Garcia H, Karlitz JJ, Massoumi H, et al. (2010) Effectiveness of Hepatitis C Treatment with Pegylated Interferon and Ribavirin in Urban Minority Patients. Hepatology 51: 1137-1143.

31. Arbuthnot $P$, Longshaw V, Naidoo T, Weinberg MS (2007) Opportunities fo treating chronic hepatitis $B$ and $C$ virus infection using RNA interference. J Viral Hepat 14: 447-459.

32. Lutchman G, Danehower S, Song BC, Liang TJ, Hoofnagle JH, et al. (2007) Mutation rate of the hepatitis C virus NS5B in patients undergoing treatment with ribavirin monotherapy. Gastroenterology 132: 1757-1766.

33. De Francesco R, Migliaccio G (2005) Challenges and successes in developing new therapies for hepatitis $C$. Nature 436: 953-960.

34. Takeshita M, Ishida Y, Akamatsu E, Ohmori Y, Sudoh M, et al. (2009) Proanthocyanidin from blueberry leaves suppresses expression of subgenomic hepatitis C virus RNA. J Biol Chem 284: 21165-21176.

35. Jensen GS, Ginsberg DI, Huerta P, Citton M, Drapeau C (2000) Consumption of Aphanizomenon flos-aquae has rapid effects on the circulation and function of immune cells in humans- A novel approach to nutritional mobilization of the immune system. JANA 2: 50-58.

36. Eisenbrand G; Senate Commission on Food Safety (SKLM), German Research (2008) Microcystins in algae products used as food supplements. Mol Nutr Food Res 52: 735-736.

37. Baicus C, Tanasescu C (2002) Chronic viral hepatitis, the treatment with spiruline for one month has no effect on the aminotransferases. Rom J Intern Med 40: 89-94

38. Yano M, Ikeda M, Abe K, Dansako H, Ohkoshi S, et al (2007) Comprehensive Analysis of the Effects of Ordinary Nutrients on Hepatitis C Virus RNA Replication in Cell Culture. Antimicrob Agents Chemother 51: 2016-2027. 